\title{
"THE WISEST OF ALL MEN": SOLOMON'S WISDOM IN MEDIEVAL JEWISH COMMENTARIES ON THE BOOK OF KINGS
}

\author{
From: Hazon Nahum: Studies in Jewish Law, Thought and History \\ presented to Dr. Norman Lamm on the Occasion of his Seventieth Birthday, \\ ed. by Yaakov Elman and Jeffrey S. Gurock (Yeshiva University Press: \\ New York, 1997), pp. 93-114.
}

The Book of Kings informs us that Solomon was granted incomparable wisdom, but it presents a narrative of his reign which stands in considerable tension with this assertion. Both religious transgressions and troubling policy decisions engender serious doubts about Solomon's judgment, and these in turn raised a series of intriguing challenges for Jewish biblical commentators in the Middle Ages.

What is the meaning of wisdom in general and of Solomon's wisdom in particular? Was Solomon granted miraculous discernment ex machina, or did this divine gift build upon impressive preexisting intellectual strengths? What is the relationship between wisdom and piety? To the extent that these are intertwined, we need to understand Solomon's real or apparent transgressions. How many sins are to be imputed to him, at what points in his life did he commit them, and how serious were they? Was his marriage to Pharaoh's daughter permissible, moderately objectionable, or profoundly sinful? Did he act knowingly or inadvertently? How should we view the multiplicity of horses, the accumulation of wealth, the many wives? Is it possible that he really worshipped idols in the straightforward sense of the term? Finally, on a more mundane but no less critical level, was he guilty of policy errors, including unconscionable levels of taxation and forced labor, that led to the political catastrophes, both foreign and domestic, which followed in the wake of his reign? 
Not every commentator appears sensitive to each of these questions, and occasionally the proposed solution is less interesting than the deeper issue of whether the problem is raised at all. As we shall see, both the threshold level of sensitivity and the modes of resolution can rest upon the overall worldview and cultural environment of an exegete and provide insights into the relationship between the reading of a biblical passage and attitudes toward fundamental issues of philosophy, politics, and faith.

\section{THE CONTOURS OF SOLOMONIC WISDOM}

What, then, was the nature of the extraordinary wisdom with which Solomon was blessed? Let us begin, as any exegete must, with the biblical data themselves. Strikingly, Solomon made the wisest decision of his life before he received his special blessing: he chose to request wisdom. In his crucial dream, he responds to the divine offer by asking God for "an understanding mind to judge Your people, to distinguish between good and bad; for who can judge this vast people of Yours?" (I Kings 3:9). God responds by praising Solomon for requesting "discernment in dispensing justice. ... I grant you a wise and discerning mind; there has never been anyone like you before, nor will anyone like you arise again" (I Kings 3:12).

Two chapters later, we are provided a more extensive definition:

The Lord endowed Solomon with wisdom and discernment in great measure, with understanding as vast as the sands on the seashore. Solomon's wisdom was greater than the wisdom of all the Kedemites and than all the wisdom of the Egyptians. He was the wisest of all men... He composed three thousand proverbs, and his songs numbered one thousand and five. He discoursed about trees, from the cedar in Lebanon to the hyssop that grows out of the wall; and he discoursed about beasts, birds, creeping things, and fishes (I Kings 5:9-13).

As to concrete, explicit applications of Solomon's wisdom, we are afforded two examples: the famous judgment determining the true mother of a child, and the ability to solve the unspecified riddles posed by the Queen of Sheba (I Kings 3:16-28, 10:1-9).

Aside from judicial discernment, which can itself be understood in many ways, the biblical material leaves us extensive leeway in interpreting 
the character of Solomon's wisdom. Despite the apparent numbers, Rashi restricts the proverbs and songs to the biblical books ascribed to Solomon, and he makes reference to a "midrash aggadah" which understands the discourses about trees, birds, and fish as halakhic discussions. Before citing this midrash, however, he presents a straightforward reading which interprets Solomon's wisdom as medical knowledge concerning trees and animals, the usefulness of particular trees as building materials, the diet of various animals, and the like. ${ }^{1}$ R. Joseph Kara, who hailed from the same cultural sphere as Rashi, exhibits similar inclinations, though he provides a lengthier, more detailed list of the scientific fields and specific questions which Solomon mastered, so that we are informed that the wisest of men knew the precise measure of a given animal's strength, whether or not it could be domesticated, whether it inhabited deserts or settled areas, and more. Almost as an afterthought, he too notes the midrashic comment explaining the passage in halakhic terms. ${ }^{2}$

Not surprisingly, we find no reference to metaphysical insights in the comments of these French exegetes. At the same time, we should not wonder about the positive assessment of practical scientific knowledge expressed in their commentaries. As I have argued elsewhere, the pursuit of natural science could become the subject of controversy precisely in the Sephardic orbit, where it was caught up in the web of philosophy. If the natural sciences were part of the "propaedeutic studies" leading to the queen of the sciences, they could be tainted by the unsavory reputation of the queen herself. Where they stood on their own, it is hard to imagine any grounds of principle for dismissing them or for failure to admire one who had mastered their secrets. The very indifference of Ashkenazic Jews to philosophical study liberated them to examine the natural world with keen, unselfconscious interest. ${ }^{3}$

1 Commentary to I Kings 5: 12-13. The midrash is in Pesiqta Rabbati, chap. 14. In commenting on the earlier verses of this passage, Rashi also alludes to astronomy, or astrology (hokhmat ha-mazzalot), and music.

2 Perush R. Yosef Kara 'al Nevi'im Rishonim, ed. by S. Eppenstein (Jerusalem, 1972), commentary to I Kings 5:13.

3 I made the basic point in Gerald Blidstein, David Berger, Sid Z. Leiman, and Aharon Lichtenstein, Judaism's Encounter with Other Cultures: Rejection or Integration?, ed. by Jacob J. Schacter (Northvale, N.J., and London, 1997), p. 118, and cf. p. 134, n. 131. The intensive study of natural science might remain problematic because it takes time from the study of Torah, but this concern is far less acute or fundamental than the issues raised by pursuit of scientific knowledge as part of the philosophic quest. 
Despite the citation of the midrash equating Solomon's wisdom with mastery of the Torah, the secondary role of this interpretation is striking. In Proverbs and Ecclesiastes, the Rabbis and traditionalist commentators routinely identified wisdom with Torah. Here, perhaps because of the plain meaning of the references to trees and beasts, perhaps because Solomon's wisdom appears to refer to the same disciplines pursued by the Kedemites and Egyptians, perhaps because of the apparent relevance of his wisdom to the riddles of the Queen of Sheba, this understanding is thoroughly marginalized.

At the other end of the ideological spectrum, Joseph ibn Kaspi provided an explanation tenuously rooted in the text and driven almost entirely by his thoroughgoing rationalism. Here is the meaning of Solomon's discoursing about trees and animals:

It is evident (mevo'ar) that this is the science of nature, which is included in the interpretation of the account of creation and the account of the chariot, held in contempt by our masses in their sinfulness. Indeed, in our sinfulness we lost the works of Solomon and other of our sages, so that matters pertaining to the intellectual disciplines are attributed to Plato and Aristotle. ${ }^{4}$

Anyone with elementary discernment, then, will see an "evident" reference in this verse to Aristotelian metaphysics, which is unquestionably how ibn Kaspi understood "the account of the chariot." Here, the connection between natural science and philosophy taken for granted by certain Provençal and Spanish thinkers enabled ibn Kaspi to expand the reference to trees and beasts to the point where Solomon's self-evident command of philosophy serves as an admonition to the obscurantist objects of the exegete's acerbic critique. In fairness, the grandiose biblical rhetoric describing Solomon's wisdom opens the door to a legitimate expansion beyond trees, beasts, and fish, but the distance between this rhetoric and a confident reference to Plato and Aristotle rests upon a series of rationalist assumptions far removed from the biblical text. ${ }^{5}$

Adnei Kesef, ed. by Isaac Last (London, 1911), commentary to 5:13, p. 47.

These include most notably the Maimonidean identification of the accounts of creation and the chariot with physics and metaphysics and the belief that Jewish wisdom was lost to its original masters, appropriated by the Greeks, and hence available to medieval Jews primarily through the study of alien texts. On the first point, see Hilkhot Yesodei ha-Torah 
Ralbag, whose intellectual profile was close to that of ibn Kaspi, provided an interpretation which stands somewhere between the readings of the Northern European exegetes and of his Provençal contemporary. Solomon knew the causes, composition, and essential traits of trees, beasts, and fish by investigating their nature, and he probably also knew the uses to which they could be put. Ralbag describes this knowledge with the technical language of philosophically oriented scientific discourse, and in a comment on Solomon's prayer several chapters later, he takes for granted the king's familiarity with the celestial intelligences and the acquired intellect. At the same time, he does not indicate in any way that the Solomonic wisdom singled out by Scripture is to be understood as the mastery of metaphysics. ${ }^{6}$

The reason for this may emerge from an examination of the position of his philosophically oriented but more conservative predecessor Radak. That position is at first a bit surprising but ultimately highly revealing. Despite his vigorous affirmation of the importance of philosophical study, Radak's understanding of these verses also attributes no special metaphysical knowledge to the wise king. Here, however, we are provided enough information to discern the explanation, which could have motivated Ralbag as well as Radak. The moment a commentator provides a definition of wisdom in our context, he is committed to the position that Solomon attained the apex of achievement in that field, surpassing all others, including Moses. Thus, it is precisely because Radak valued philosophy so highly that he refrained from identifying it with Solomon's wisdom; such an identification would have forced him to affirm that the greatest of prophets was not the greatest of philosophers. Solomon, says Radak, achieved ultimate superiority in the science of nature (hokhmat ha-teva'), but in the divine science (ba-hokhmah ha-elohit), Moses was greater than he. ${ }^{7}$

Abravanel, the final commentator that I will examine in this study, was, like Radak, a philosophically oriented exegete with a conservative

2:11-12; 4:10, 13; Hilkhot Talmud Torah 1:11-12. Cf. Isadore Twersky, Introduction to the Code of Maimonides (Mishneh Torah) (New Haven, 1980), pp. 488-507. On the second, see the material collected in Norman Roth, "The 'Theft of Philosophy' by the Greeks from the Jews," Classical Folia 22 (1978): 53-67.

6 Commentary to 5:13, and cf. Commentary to 8:23.

7 Commentary to 3:12, and cf. to 5:12. See Maimonides, Guide 3:54, and Sara Klein- Braslavy, Shlomo ka-Melekh ve-ha-Esoterizm ha-Pilosofi be-Mishnat ha-Rambam (Jerusalem, 1996), pp. 121-123. 
bent. In his case, however, this orientation led to more complicated conclusions. Like ibn Kaspi, Abravanel was unwilling to limit the wisdom described with such sublime rhetoric to a single field of endeavor. Solomon's intellectual perfection embraced the totality of wisdom. Indeed, Abravanel exploited this opportunity to write a lengthy excursus on the nature of wisdom itself, the categories of which it is comprised, and its limitations. ${ }^{8}$

This approach, however, forced him to confront the apparently unavoidable conclusion that Solomon was superior to Moses and all the other prophets in every form of wisdom despite the inextricable connection for medieval philosophers between prophecy and intellectual perfection. It is almost painful to observe Abravanel's acute discomfort with this dilemma and his difficult struggles to extricate himself from its grasp. Perhaps there is, after all, no intrinsic connection between wisdom and prophecy. Perhaps there is, but the former is not necessarily proportional to the latter. Perhaps it is proportional, but this is the case only for the highest forms of knowledge, not for the lower forms (management of household and state) in which Solomon excelled but Moses needed the advice of Jethro. (And so we watch incredulously as Solomon's perfection in the totality of wisdom, underscored in page after page of Abravanel's excursus, fades into anticlimax.) $)^{9}$ Finally, perhaps the unqualified Scriptural assertion that Solomon was wiser than all who came before or after him refers only to those who failed to attain prophecy. ${ }^{10}$

To a certain degree, Abravanel deflects the full force of the question by arguing that Solomon obtained his wisdom miraculously, so that it may not be governed by the usual rules of nature. The immediate impetus to this position was Ralbag's hypernaturalistic assertion that the assurance of unique wisdom is incomprehensible, since nothing, not even a miracle, can provide a person with intellectual gifts that could not be attained to an equal degree by a later individual. ${ }^{11}$ Abravanel's sharp retort is that

$8 \quad$ Perush 'al Nevi'im Rishonim (Jerusalem, 1955), pp. 466-480.

9 The suggestion is especially striking in light of the fact that in one of his preliminary questions (p. 451), Abravanel explicitly rejected Radak's assertion that Solomon's blessing was confined to natural science and did not extend to metaphysics.

10 Pp. 479-480.

11 Ralbag to 3:12. On another occasion, I hope to address the tension between Ralbag's denial of this possibility with respect to wisdom and his affirmation of precisely this reality regarding Mosaic prophecy. 
Ralbag's belief in miracles and divine power is sorely wanting if he thinks that God could not miraculously grant Solomon the ability to be wiser than he. ${ }^{12}$

This position leads Abravanel to an extremely strong formulation of the miraculous nature of Solomonic wisdom. On the evening of Solomon's dream, he went to sleep as "a brutish man who does not know, and he awoke wise as an angel of God."13 The first part of this sentence is, of course, hyperbole, and it would be unfair to Abravanel to hold him to it in its literal sense. On the one hand, the perception that Solomon's wisdom was miraculous guides Abravanel's understanding of both Scriptural examples of the practical application of this wisdom; on the other, his deviation from the assertion that Solomon was without prior intelligence is sometimes so sharp that it appears inconsistent even with a discounted version of that assertion.

Let us begin with the examples. The Queen of Sheba, says Abravanel, was interested precisely in the supernatural quality of Solomon's discernment. The solutions to the riddles she proposed were based on her subjective understanding; no one could have perceived her intentions naturalistically. The fact that Solomon provided precisely the interpretations which she had in mind demonstrated conclusively that his knowledge was of divine origin. ${ }^{14}$ At first glance, it is truly remarkable that this interpretation, whose emphasis on the miraculous apparently results from Abravanel's rejection of Gersonidean naturalism, is derived from Gersonides himself. To Ralbag, Solomon's experience exemplifies the fundamental truth that knowledge can be obtained in a dream without the usual intellectual effort; ${ }^{15}$ precisely because such knowledge was obtained in atypical fashion, it appears that its beneficiary might achieve insight that goes beyond the information available through logical reasoning. ${ }^{16}$ Despite their very different views of the scope and nature of miracles, both Ralbag and his most distinguished critic agree that it was a form of nonrational perception which provided Solomon

P. 471.

Ibid.

Commentary to $10: 2$, pp. 540-541.

Commentary to I Kings 11, to'elet 3.

Commentary to I Kings 10:1: The queen wanted to see "if [Solomon] would determine the secrets that she had in mind in these riddles, for in this manner one can test if this wisdom is a gift of God. If it is, he would be able to discern her intention even though [the riddles themselves] are susceptible of other interpretations." 
with his success in deciphering the riddles of the queen. ${ }^{17}$

With respect to the second practical application of Solomon's wisdom, Abravanel and Ralbag present contrasting approaches. The latter expresses the straightforward understanding that Solomon determined the true mother by a clever, rational ruse. To Abravanel, on the other hand, the famous stratagem appears insufficiently impressive; no "great wisdom" was needed to think of it. What really happened was that Solomon identified the true mother from an examination of the litigants' facial expressions alone, and he communicated his conclusion to his aides; only then did he pursue his stratagem to demonstrate that he had been correct. ${ }^{18}$ Needless to say, there is not a sliver of textual evidence for this interpretation, which results either from Abravanel's commitment to his portrait of supernal wisdom or from personal experience with intrigues in royal courts that made Solomon's creative trickery seem entirely routine.

Despite Ralbag's affirmation that wisdom can sometimes be attained through dreams and prophecy without the usual effort, medieval philosophers did not believe that divine inspiration rests on individuals bereft of any preparation. In light of this conviction, Abravanel's assertion of Solomon's thorough ignorance before the dream was highly problematic. Near the beginning of the Commentary to Kings, he writes that David was concerned that Solomon, in the typical manner of youths, would be unduly influenced by Shimi son of Gera's flattering behavior toward him; ${ }^{19}$ in fact, however, Solomon's decision to send Shimi away should be seen not as a mechanical act of obedience to his father's final wishes but as a display of intelligent initiative. ${ }^{20}$ Much more strikingly, Abravanel's summary of Solomon's reign asserts that David's references to his son's wisdom at the beginning of Kings demonstrate "that Solomon had natural preparation for wisdom before the dream, and that knowledge was added to him through a divine overflow in a

17 On Abravanel's critical stance toward Ralbag, see Menachem Kellner, "Gersonides and his Cultured Despisers: Arama and Abravanel," Journal of Medieval and Renaissance Studies 6 (1976): 269-296.

18 Commentary to $3: 24$, p. 482.

19 Commentary to $2: 8$, p. 448.

20 Commentary to $2: 36$, p. 457 . Note too his assertion that Solomon had to be no less than twenty years old when he became king in light of his understanding of the policies necessary to sustain his rule; see Commentary to 3:7-8, p. 466. 
prophetic manner."21 Indeed, the gold in the Temple, which symbolizes Solomon, was affixed to the cedars, which represent David, to indicate the intimate connection through which Solomon, who was similar to his father, inherited wisdom from him along with kingship. ${ }^{22}$ Hardly "a brutish man who does not know."

\section{WISDOM AND RELIGIOUS TRANSGRESSION}

The varying perceptions of Solomon's wisdom inevitably affect the approaches to his real or apparent sins. In principle, it seems reasonable to assume that a commentator who understands this wisdom as primarily scientific and who does not see the natural sciences as a step toward the knowledge of God will face only minor obstacles in accepting the reality and, within limits, even the gravity of Solomon's transgressions. On the other hand, a broad understanding of Solomonic wisdom makes it more difficult to understand how such an individual could have sinned, particularly in light of the standard philosophical approach which saw sin as an intellectual, not merely a moral failing, and which encouraged developing the faculty of reason as the most effective weapon against the evil inclination.

Solomon's marriage to Pharaoh's daughter, which appears to violate the biblical injunction against marrying an Egyptian, took place before the dream. Needless to say, the focus of this study on Solomon's wisdom should not obscure the obvious: traditionalist commentators were disturbed by the sins of biblical heroes even in the absence of a special

21 Commentary to chapter 11, p. 551.

22 Commentary to chapter 8, p. 521.

Commentators outside the philosophic tradition could presumably have affirmed Solomon's ignorance prior to the divine gift of wisdom with equanimity. Nonetheless - though I would be hesitant in the extreme to draw confident conclusions from this evidence - it is at least worth noting an intriguing passage in the Sifrei cited by Rashi in his commentary to Deuteronomy 1:9. "Is it possible that the one of whom it was written, 'He was the wisest of all men' would say 'For who can judge [this vast people of yours]?'?" The glaring difficulty in Rashi's - or the Sifrei's - question is that Solomon became the world's wisest man as a result of his comment about the difficulty of judging. There appears to be an instinct at work here which cannot imagine that unparalleled wisdom would be granted to one who was not already exceptionally wise. (So Siftei Hakhamim ad loc., though cf. Maharal's Gur Aryeh ad loc.) 
bestowal of discernment. ${ }^{23}$ In our case, the problem was sharpened by the assumption of several exegetes that Solomon was exceedingly wise even before the dream and by the persistence of the marriage even after it.

Rashi, who is not likely to see a special connection between piety and Solomonic wisdom, understands this union as a straightforward transgression. Following Rabbinic precedent, he remarks that as long as Solomon's teacher Shimi was present, he did not establish a marital relationship with Pharaoh's family; we see, then, the critical importance of residing near one's teacher. Moreover, Rashi endorses Seder Olam's rearrangement of the chronological order of I Kings 3 in order to blunt the appearance of the verse "And Solomon loved the Lord" (3:3) immediately after this forbidden marriage. ${ }^{24}$

R. Joseph Kara goes even further by taking the apparently neutral phrase "And he brought her to the city of David" (3:2) as evidence of compounded transgression. "Know that this point is mentioned by Scripture to indicate improper behavior. This place was designated for holiness, since the city of David, which is Zion, is where the ark of the divine covenant was brought; and this man brings Pharaoh's daughter there." 25 The comment was no doubt triggered by the Chronicler's report (II Chron. 8:11) that Solomon eventually removed Pharaoh's daughter from the city of David for this very reason, but the critical reference here clearly goes beyond what the verses require and reflects a relatively low threshold of resistance to intensifying the sin of a biblical figure.

Ralbag too extends and heightens Solomon's sinfulness with respect to his marriages, but he does not do so until chapter 11 , where the biblical text itself sharply criticizes the king's behavior. The tone of Ralbag's

See my "On the Morality of the Patriarchs in Jewish Polemic and Exegesis," in Understanding Scripture: Explorations of Jewish and Christian Traditions of Interpretation, ed. by Clemens Thoma and Michael Wyschogrod (New York, 1987), pp. 49-62; reprinted in Modern Scholarship in the Study of Torah, ed. by Shalom Carmy (Northvale, N.J., and London, 1996), pp. 131-146. Also see Avraham Grossman, Hakhmei Zarfat ha-Rishonim (Jerusalem, 1995), pp. 488-492.

24 Commentary to 3:1. Rashi (to 11:39) also cites Seder Olam's assertion that a thirty-sixyear punishment was initially set for the Davidic kingdom to correspond to the thirtysix years that Solomon was married to Pharaoh's daughter. So too Radak to 11:39 and R. Joseph Kara to 11:41.

25 Commentary to 3:1, where he also makes reference to the Rabbinic comment about Shimi. 
comment in chapter 3, where Pharaoh's daughter is first introduced, differs markedly, and the difference reflects a crucial point which can often determine an exegete's approach. The changing local contexts of biblical data may lead to profoundly different emphases and even to outright inconsistencies in a commentator's approach. Thus, the report of the questionable marriage in chapter 3 is followed immediately by the assertion that Solomon loved the Lord though he continued to sacrifice at a variety of shrines. We have already seen how this juxtaposition disturbed Rashi and Seder Olam, and the reference to the shrines as the only exception to Solomon's love of God further strengthens the implication that the marriage was unobjectionable. At this point, then, Ralbag writes, "It is appropriate for you to know that Solomon married into Pharaoh's family after the latter's daughter converted; nevertheless, this was a slight deviation (yezi'ah qezat) from the ways of the Torah, which permitted Egyptians to enter the community only in the third generation." 26 It is difficult to envision a milder formulation.

In chapter 11, we find ourselves in a different world. Here, we no longer encounter a Solomon who loved the Lord, but one who

loved many foreign women in addition to Pharaoh's daughter-Moabite, Ammonite, Edomite, Phoenician, and Hittite women, from the nations of which the Lord had said to the Israelites, "None of you shall join them..." Such Solomon clung to and loved... And his wives turned his heart away (vv. 1-4).

So we search Ralbag's commentary in vain for a marriage which constituted a "slight deviation" from the ways of the Torah.

If someone will argue that it is appropriate for us to believe that [these foreign women] converted before Solomon married them, we would nonetheless be unable to avoid a conclusion of improper behavior (genut). Pharaoh's daughter, after all, was prohibited from entering the community of the Lord because only the third generation is permitted to do so. Moreover, Ammonite and Moabite women also come from a nation unworthy of entering the community..., and even though the females among them were not forbidden to enter the community..., it was inappropriate for a king to marry them, since it was impossible for the offspring that he would have from them to be truly perfect. ${ }^{27}$

26 Commentary to $3: 1$.

27 Commentary to $11: 1$. 
A genuine exegetical problem is certainly at work here, since the verses appear to imply that Solomon's marriages to women from nations other than Egypt were forbidden, while the halakhah actually permits marriage to converted women from all the peoples on that list. Nonetheless, the reference to necessarily deficient offspring is not forced upon Ralbag-indeed, Solomon's own descent from a Moabite convert named Ruth makes it highly problematic - and while we do not face a full-fledged contradiction, the attitude toward the truly forbidden marriage is considerably less forgiving than it was when the king who contracted it loved the Lord. ${ }^{28}$

The juxtaposition between Solomon's marriage and the reference to his love of the Lord led other commentators to remarkable conclusions. Radak argued that the biblical account here reveals that the Talmudic sage who limited the prohibition against marrying Egyptians to their males was correct (nir'in devarav) despite the fact that "the halakhah has not been fixed in accordance with [his] view." 29 Abravanel tells us that if he were to approach this question "according to the plain meaning of the verses," he would argue that Solomon did not sin at all, and what follows is a veritable assault upon standard Rabbinic law on this point. First, there is the rejected position cited by Radak which Solomon, who was, after all, one of the Sages, might have endorsed. Moreover, "the third generation" could begin from the Exodus, not from each act of conversion; even if the count begins with conversion, the assertion that the third generation "will enter" may mean that at this juncture such a step becomes a quasi-obligation (be-hiyyuv u-mi-derekh mizvah), but it is permissible even earlier; finally, "entering the community" may not mean marriage at all but admission to positions of leadership.

Only after this lengthy and vigorous presentation of the thorough rejection of Rabbinic law that a straightforward examination of the text would have impelled Abravanel to propose does he assert that the position of the Sages constitutes the transmitted truth (ha-mequbbal ve-

28 In his retrospective evaluation at the end of the biblical account of Solomon's reign, Ralbag goes so far as to say that the ultimate exile and destruction of the Temple resulted from the king's failure to heed the divine admonition that he command his children to observe the ways of the Lord (to'elet 33 at the end of chapter 11). This sin is nowhere in the biblical text and appears to be a deduction based on the behavior of Solomon's descendants.

29 Commentary to 3:3. See B. Yevamot 77b. 
ha-amitti). The correct position, then, is that Solomon misinterpreted the law; he believed that after the conversion of Pharaoh's daughter he was permitted to marry her, and since this was the honest error of a young man motivated by understandable diplomatic considerations, God did not punish him for it. ${ }^{30}$

What Abravanel does not address is a problem which appears to follow from his all-embracing view of Solomon's wisdom after the dream. Among many other things-one is tempted to say, among all other things-Solomon was expert in "the commandments. He knew them in general and encompassed their particulars down to the most precise minutiae, just as Moses our teacher, may he rest in peace, received them from God without the slightest doubt or dispute."31 At that point, we would imagine, Solomon should have divorced his prohibited wife. Abravanel, however, refuses to ascribe any blemish to Solomon after his dream and before the sins of his old age, so that the problem of this marriage, which had already been resolved in the Commentary to chapter 3 , is not permitted to rise up again to taint the perfection of the wise king at the height of his powers. ${ }^{32}$

Solomon's proliferation of wives, wealth, and horses stands in stark contrast to the injunctions in Deuteronomy 17 concerning proper royal behavior. Rashi, R. Joseph Kara, Radak, and Ralbag all acknowledge this behavior as sinful, in some cases with explicit or implicit reference to the Rabbinic assertion attributing the transgressions to Solomon's selfconfidence. Since the Torah makes clear that it is primarily concerned with the results that normally follow from the actions it has prohibited, Solomon concluded that an individual of his discernment could perform the acts and avoid the consequences. ${ }^{33}$ To Ralbag, the sins resulted

30 Commentary to $3: 1$.

31 P. 477.

32 The reference in I Kings 3:3 to Solomon's worship at multiple shrines raises a problem which is the mirror image of the marriage to Pharaoh's daughter. Here the Bible appears to condemn behavior which Rabbinic law considered permissible before the period of the Temple. Rashi (to 3:3) and R. Joseph Kara (to 3:2) see this as a criticism of Solomon's delay in building the Temple. Radak and Abravanel (to 3:3) regard it as a deviation from David's practice and consider it objectionable because it can lead to idolatry (Radak) or unspecified sin (Abravanel). Ralbag to 3:3 and in to'elet 2 at the end of chapter 11 apparently finds nothing wrong in behavior whose purpose he sees as the attainment of prophecy. In to'elet 1 , however, he acknowledges the criticism implicit in the biblical formulation and indicates that such worship is flawed, though permissible.

33 See Radak to 11:1 and Rashi to Ecclesiastes 1:18. Also see R. Joseph Kara to 10:28 and 
not from Solomon's reliance on his wisdom but from a powerful desire which prevailed despite that wisdom. ${ }^{34}$ None of these commentators was committed to a portrait of Solomonic perfection like that of Abravanel, and the Rabbinic affirmation of sin easily removed whatever inhibitions may nonetheless have remained. For Abravanel himself, the issue was more difficult, and we shall look at his approach when we examine the question of errors in royal policy.

For all commentators, one sin ascribed to Solomon violates the canons of both wisdom and piety so severely that it could not be suffered with equanimity.

In his old age, his wives turned away Solomon's heart after other gods... Solomon followed Ashtoreth the goddess of the Phoenicians, and Milcom the abomination of the Ammonites... Solomon built a shrine for Chemosh the abomination of Moab... and one for Molech the abomination of the Ammonites. And this he did for all his foreign wives who offered and sacrificed to their gods (I Kings 11:4-8).

Following Talmudic precedent, Rashi and Radak insist that Solomon was faulted for failing to prevent his wives from worshipping idols, not for doing so himself. ${ }^{35}$ Ralbag draws an explicit connection between Solomon's wisdom and the inconceivability of attributing idolatry to him personally; such a man could not have followed "these vanities and abominations given the fact that he grasped the Lord, may He be blessed, to a greater degree than others," not to speak of the fact that he wrote works under divine inspiration and twice experienced revelation directly. ${ }^{36}$

Abravanel repeats Ralbag's argument, ${ }^{37}$ but he goes further by attempting to establish an almost direct causal link between Solomon's wisdom and the idolatry of his wives. Through his unique wisdom, Solomon understood "the modes of service relating to the celestial powers assigned to the nations [of his wives] through which the overflow

\section{1:1. Cf. B. Sanhedrin 21b.}

34 To'elet 36 at the end of chapter 11, where Solomon is described as homeh el ha-nashim and possessed of a yezer leharbot sus.

35 Rashi to 11:7; Radak to 11:1.

36 Commentary to 11:4.

37 Commentary to $11: 1$, p. 546. 
could be lowered upon those nations."38 Abravanel suggests that when the Gentiles flocked to learn Solomon's wisdom, it was this wisdom that they sought. Such instruction was not sinful in light of Deuteronomy 4:19, which asserts that God assigned the heavenly hosts to the nations of the world. ${ }^{39}$ Later, however, Solomon imparted this knowledge to his wives, who put it into practice in idolatrous rites which he tolerated. By transforming the king from a passive tolerator of idolatry into an active participant in imparting its intellectual underpinnings, Abravanel has gained the exegetical advantage of accounting for very strong biblical language, but the damage to Solomon's image is not inconsiderable.

Abravanel has also gained something else; he has constructed a bridge which can bring us from the paragon of wisdom and piety that we have known until now to the sinful—and unsuccessful—ruler of I Kings 11. What Solomon did was teach wisdom to his wives-and precisely that wisdom which he had taught other Gentiles without incurring divine wrath. Nonetheless, the effect of his action was the facilitating of idolatry, a grave offense worthy of severe punishment. At this point, the miraculous nature of Solomon's ascent to the heights of wisdom becomes his undoing. Wisdom, power, and wealth all depart from him.

Just as these perfections had rested in his home, so they left him. They came in a divine manner and with a supernal overflow, not in a natural fashion. When he separated himself from his God so that the thread of grace which had always descended upon his head was severed, those perfections departed along with the overflow which was their cause. 40

Abravanel's Solomon, then, moves from a youth of considerable potential but little understanding to a maturity marked by unique, miraculous wisdom, to an old age that might well be characterized in the words of the wisest of men as that of "an old and foolish king who no longer has the sense to heed warnings" (Eccles. 4:13).

Despite the gravity of Solomon's sin, even Abravanel does not

38 Ibid. So too in the excursus on wisdom, p. 475.

39 An even stronger, surprisingly explicit assertion that this verse frees Gentiles from the obligation of monotheism appears in Abravanel's contemporary, R. Isaac Arama; see his 'Aqedat Yitzhak, chapter 88, p. 16a, and his Hazut Qashah, chapter 12, p. 32b. I hope to discuss Arama's comments, which appear to contradict the unambiguous position of Talmudic law, in another context.

40 Commentary to chapter 11 , p. 552. 
maintain that he himself committed idolatry. Ironically, it was precisely a commentator of an extreme philosophical bent, a man for whom it was virtually inconceivable that a philosopher of Solomon's stature could commit such a sin, who constructed a solution so radical that anything became possible. We will recall that Joseph ibn Kaspi regarded Solomon as a metaphysician par excellence. How, then, could he have been caught up in idolatry?

Although ibn Kaspi makes no reference to Maimonides, the inspiration for his answer emerged, I believe, from a famous passage in The Guide of the Perplexed. Maimonides conveys to us "a most extraordinary speculation" to explain how people who have achieved a high level of apprehension of God could nonetheless find themselves unprotected by divine providence. Occasionally, he explains, even such a person allows his attention to stray so that "for a certain time" his thought "is emptied of God," and "providence withdraws from him during the time when he is occupied with something else." 41

Moses' intellect, says ibn Kaspi, was actively engaged with God without interruption, but Solomon turned away to some degree precisely because he was capable of being distracted. His wives disrupted his concentration to a limited extent even in his youth, but at that point this spiritual detour

did not reach the point where he would worship other gods, which is the heresy called 'avon [iniquity] in Hebrew; it did, however, reach the point where there was some deficiency in his apprehension. At the very least, there were moments (ittot) at that time in which his intellect was potentially iniquitous, and this is what is called het [sin] in Hebrew. ${ }^{42}$

Once ibn Kaspi had discovered a mechanism which neutralized Solomon's supernal wisdom, nothing was ruled out, and it is apparently his position that in the king's old age, his wives turned him away to the point where he actually worshipped foreign gods.

41 The Guide of the Perplexed, translated by Shlomo Pines (Chicago, 1963) 3:51, pp. 624-625.

42 Commentary to 11:3. The editor (Adnei Kesef p. 51) notes that V. Aptowitzer suggested that ittot be emended to "ivrut. Once one is aware of the Maimonidean basis for ibn Kaspi's suggestion, the impropriety of this emendation becomes self-evident. (In light of our earlier discussion about Solomon and Moses, it is worth underscoring ibn Kaspi's explicit assertion that the latter, whose apprehension of God never flagged, was wiser than the former.) 


\section{THE ROYAL POLICY OF THE WISEST OF KINGS}

It has become abundantly clear that for some commentators, the problem of Solomon's sins was significantly exacerbated by the reports of his exceptional wisdom. For others, who limited the sphere of his wisdom and saw no intimate relationship between such wisdom and piety, the connection was tenuous and marginal. But Solomon was arguably guilty of more than religious error. His taxes and corvées, expensive building projects, lavish palace life, and elaborate stables appear to have engendered smoldering resentment which exploded into flame after his death, destroying the Davidic empire and rending the fabric of Israel. What are we to make of fundamental policy errors by the wisest of men?

Rashi and R. Joseph Kara do not raise the question and are apparently untroubled by it. This may be because their commentaries tend to focus on the verses immediately before them, and this problem-if it is a problem-arises only when one steps back and looks at the entire picture. ${ }^{43}$ In their immediate context, the biblical accounts of taxes and building projects are part of the description of a glorious, highly successful reign. Equally or even more important, the Northern European commentators probably saw the rebellions of subject kings and the internal resistance that culminated in secession in purely religious terms. These were divine punishments for Solomon's sins and need not be connected to his policies by natural causation.

Radak and Ralbag explicitly defend Solomon against the people's charge that he had imposed a heavy yoke upon them (I Kings 12:4). At earlier points in the commentaries, we were informed that the difficult labor was done entirely by non-Israelite peoples. Both exegetes maintained that the only corvée affecting real Jews was the one in Lebanon, and Ralbag took pains to point out that it was arranged so that the work would not be unduly burdensome. ${ }^{44}$ To Radak, the complaints expressed to Rehoboam about Solomon's taxation were entirely unjustified.

$43 \quad$ For a related observation about Ashkenazic polemicists, see my forthcoming study, "On the Uses of History in Medieval Jewish Polemic against Christianity: The Search for the Historical Jesus," in the Festschrift for Yosef Hayim Yerushalmi.

44 See Radak on 5:27, Ralbag on 5:29 and 9:23, and to'elet 15 at the end of chapter 11 . Cf. Rashi on 5:30 and R. Joseph Kara on 5:29-30 and 9:23. 
They lived in great tranquility in his time, so that the entire taxation was easy for them... Rather, God saw to it that they should concoct an accusation in their discussion with Rehoboam so that they should secede and crown Jeroboam. 45

Ralbag reiterates the same point, though his more naturalistic orientation impels him to explain the complaint not by an appeal to divine intervention but as the result of the recent wars. Still, Ralbag asserts that even now the request was for nothing more than a "slight" alleviation of the burden, an elaboration of the biblical information which underscores the reasonableness of Solomon's policies. ${ }^{46}$ Indeed, one of the lessons to be drawn from the account of Solomon's reign is precisely that the king should impose taxes and corvées to support his household and his projects. ${ }^{47}$ Both Radak and Ralbag may well have sought to avoid unforced criticism of Solomon, but their position also appears to result, at least in the case of Ralbag, from a genuine political conviction about the acceptability, even desirability, of substantial royal taxation.

On this issue, Abravanel's stance is particularly instructive. He himself served as a courtier for more than one king, and his complex but fundamentally critical approach to monarchy is well known. ${ }^{48}$ It is, then, striking though not surprising that he is the only one of the six exegetes I have examined who evinces sensitivity to the dangers inherent in Solomon's life of ostentatious luxury supported by onerous taxes. As we have seen, however, it is his position that at the height of Solomon's career, the king was blessed with all-embracing wisdom which would presumably have prevented serious errors. Even when Abravanel

45 Commentary to $12: 4$.

46 Commentary to 12:4.

47 To'elet 10 at the end of chapter 11 . It is especially striking that at the conclusion of this to'elet affirming the desirability of such royal actions, Ralbag writes, "And this has already been explained as well in Samuel's statement when he explicated the law of kingship." But in his comment on Samuel's oration (I Samuel 8:11), Ralbag took the position that the provisions of "the law of the king" are not in fact legal rights but reflect Samuel's desire to make the people fearful of actions the king will take in violation of the laws of the Torah.

48 Aviezer Ravitsky has recently provided an analysis of some aspects of this issue in "Kings and Laws in Late Medieval Jewish Thought: Nissim of Gerona vs. Isaac Abrabanel," in Scholars and Scholarship: The Interaction between Judaism and Other Cultures, ed. by Leo Landman (New York, 1990), pp. 67-90; see notes 10 and 11 of his study for some of the other secondary literature. 
retreated for a moment and raised the possibility that this wisdom might, after all, have been concentrated in a particular area, that area, we will recall, was precisely "the management of household and state." How, then, could Solomon in his prime have pursued policies which sowed the seeds of disaster?

The answer is that such policies are indeed unwise, but Solomon never pursued them. Like Radak and Ralbag, Abravanel maintains that the heavy labor was done by non-Israelites, ${ }^{49}$ but he goes further than his predecessors in several respects. First, he underscores how objectionable these policies would have been had Solomon really pursued them. Scripture, he says, informs us of the true source of the king's taxes to prevent anyone from asking the following indignant questions:

Where did Solomon obtain all these resources which he expended upon the Temple, his own palace, and other matters? Did he impose a tax upon his nation and his righteous subjects, or did he confiscate their wealth by force in accordance with the law of the king which Samuel mentioned to Saul?50

Second, he maintains that even the Gibeonites, who were the ones assigned the difficult physical labor, "surely agreed to do this willingly."51 Third, he insists that monetary taxation came entirely from non-Jewish merchants engaged in international trade, "not from those doing business inside his kingdom as the commentators thought." Solomon imposed tariffs similar to those that exist in the medieval Christian and Islamic worlds. "None of Solomon's wealth which he garnered came from his servants. He took nothing from them by authority of the law of the king; rather, it all came to him from the Gentile countries outside of his kingdom." 52 The reader comes away from this passage with the unmistakable impression that Solomon's Jewish subjects paid nothing at all before the imposition of war-related taxes in the king's old age, though in the analysis of the later complaints to Rehoboam, Abravanel does acknowledge the existence of a substantial burden of taxation, which he appears to consider entirely justified, even at the height of the reign. ${ }^{53}$

49 Commentary to 5:29, p. 492, and to 9:20, p. 539.

50 Commentary to 9:15, p. 539. Note the contrast to Ralbag's to'elet 10 cited in note 47 above.

51 Commentary to $5: 29$, p. 492.

52 Commentary to $10: 15$, p. 542. Cf. too the excursus on wisdom, p. 476.

53 Commentary to $12: 4$, p. 554. 
Finally, Abravanel repeatedly lavishes unstinting praise upon a policy as problematic as the accumulation of horses, which raises the specter of outright sin. He cites and rejects the Rabbinic assertion that Solomon violated the Deuteronomic prohibition, which applies, after all, only to an excess of horses beyond what the interests of the state require. The king's horses, he says, were a source of glory and, more to the point, a deterrent to any would-be aggressor; this was the very reason for the peace that Solomonic Israel enjoyed. ${ }^{54}$

Unlike the other commentators, Abravanel is also sensitive to the problem of Solomon's profligate spending.

One might ask: Even though Solomon possessed extensive wealth, why did he spend it so freely? After all, this would inevitably cause it to dwindle so that he would become impoverished.

The answer is that enormous supplies of gold were constantly arriving as a result of foreign trade, so that there was no danger that the kingdom's wealth would be depleted. ${ }^{55}$ Later, however, after his sin, Solomon had to impose taxes both because of wars and because-for reasons Abravanel does not specify-he stopped sending out merchant vessels while still requiring substantial income to support his lavish way of life. ${ }^{56}$ One wonders whether this was not precisely the possibility that Solomon should have foreseen. Abravanel's implicit response, I think, is that because these problems arose only as a result of sin, Solomon did not need to consider them earlier, given his reasonable, though ultimately incorrect assumption that he would remain a righteous man.

Abravanel, then, is acutely attuned to the political dangers inherent in the policies that Solomon appears to have pursued. Although his perception of Solomonic wisdom prevents him from ascribing error to Solomon in his prime, he does not solve the problem by endorsing such policies. The solution is to deny that Solomon pursued them, to ascribe them to his old age, or to argue, as in the case of lavish spending, that special circumstances justified them in this unusual, perhaps unique situation.

54 The excursus on wisdom, p. 476; Commentary to 5:8, p. 487, where he cites the Talmudic indictment; Commentary to 10:26, p. 544; the summary of Solomon's reign in chapter 11, p. 551. In his commentary to Deuteronomy 17:14-20, he notes the Talmudic passage without disagreement.

55 Commentary to $10: 22$, p. 543.

56 Commentary to $11: 40$, p. 550. 
While Abravanel cannot entirely avoid flashes of inconsistency, he stands out in his attempt to step back from the immediate context and see the overarching pattern of the narrative. The result is a dynamic portrait of Solomon that allows for a sharply drawn characterization at any given moment. For most commentators, the king was a complex figure of some ambiguity even at the peak of his powers-glorious, brilliant, yet moderately flawed. Abravanel's Solomon, on the other hand, was almost infinitely wise and virtually perfect from the moment of his dream until the sin of his old age, but before and especially after that period his defects were considerable and even decisive. Not flawed greatness, but unrealized potential followed by perfection followed in turn by fatal sin.

The varied perceptions of Solomon's wisdom and the consequent disparities in the evaluation of his piety and policy reflect fundamental differences in the cultural environments and worldviews of the exegetes we have examined and tell us a great deal about the complex interplay between texts and their interpreters. The attitude toward metaphysics, the place of the sciences, political theory, the courtier experience, a narrow or broad exegetical focus, a naturalistic or miraculous orientation, varying degrees of resistance to ascribing sin to biblical heroes, the readiness or refusal to deviate from Rabbinic tradition and interpretation-all these play a role, sometimes peripheral, sometimes significant, sometimes decisive, in the application of medieval wisdom to an understanding of the wisest of men. 